\title{
Libraries and Liberal Arts Colleges: Tough Times in the Eighties
}

\begin{abstract}
The 1980s will be a difficult period for liberal arts colleges. Fiscal support will be insufficient to meet institutional needs. Private colleges will suffer, and their libraries will suffer particularly. Ironically, this will occur at a time in which the growth of scholarly publication will decline-providing these libraries with increased opportunity, if they can preserve their fiscal support, to acquire the materials that they need. Although the prospects are grim, strategies for adaptation and successful survival exist, and they must be undertaken by colleges and their libraries in the difficult years ahead.
\end{abstract}

\section{INTRODUCTION}

Let me get right to the point. The argument I want to make is as follows:

1. Liberal arts colleges are going to have an extremely hard time in the 1980 s, but not primarily because of the demographic decline. The demographic decline is a serious challenge to the creativity and resilience of liberal arts colleges, but they are resilient, and having to respond to the altered demography might, in a healthy economy, stimulate much valuable change.

2. However, change requires capital to finance the reallocation of resources currently in place and to finance new ventures, and capital will not be widely available, especially to the institutions that need to change the most.

3. Therefore, the demographic decline will very quickly have a major negative impact on a large proportion of the private liberal arts colleges and on most private universities as well. American higher education will become more homogeneous in the next decade, an outcome that I believe to be unfortunate for the consumers of higher education in this country.

4. The libraries at these institutions, already starved in the 1970 s, will shoulder a disproportionate share of the budget cuts be-

Daniel Sullivan is vice-president for planning and development, Carleton College, Northfield, Minnesota. cause library materials expenditures are easier to cut than people. Because of the relative unavailability of capital, most institutions will not be able to adopt laborsaving and material-saving library technologies. Large initial investments must be made while the savings come much later.

5. All of this will occur, ironically, precisely at the point in history when libraries finally have a chance to have their collections grow at least as fast as the growth of knowledge.

6. While I am extremely pessimistic about the future of liberal arts colleges, I believe that realistic and possibly successful strategies for adaptation exist, and that they must be tried even given the adverse atmosphere. Institutions need to undertake honest analyses of their strengths and weaknesses relative to the competition; they must analyze the availability of alternative markets; they must explore alternative products; and they must aggressively pursue needed capital.

\section{The 1980 os Have Arrived}

The 1980 s have arrived. The 1980 s refers, in our circles, of course, to a by now welldefined set of challenges before American higher education, presented by the vagaries of demography, fundamental problems with the economy, and the government's attempts to respond to them. The sizes of the age cohorts traditionally served by undergraduate colleges have begun to decline, and this is taking place in an economic environment 
which is almost maximally unfavorable to higher education. The economic environment became less favorable a little over a decade ago, and as a result the 1970 s were a struggle for all of us. There is a good chance that the 1980s will be much worse. The demographic problem, or at least our recognition of it, is more recent in origin, but its character is much more fixed and certain than that of the economy.

In spite of the certainty of the demographic decline and of some of its consequences, there was a widespread hope in the groves of academe that the market would respond by itself to the excess supply of educational services now available, without adaptive change on the part of institutions to stimulate new demand. Many people were absolutely buoyant last spring when the Chronicle of Higher Education was reporting large increases in applications to both public and private institutions. Their buoyancy had to be misguided, however, because the number of eighteenyear-olds in the population is less this year than last, and no major changes intended to stimulate demand have been accomplished in higher education generally.

Sure enough, in its September 2 issue, the Chronicle reported the results of a survey of admissions officers at 581 private institutions by the National Institute of Independent Colleges and Universities: the number of freshmen in private institutions this fall is down 2.2 percent, and overall enrollment is down .6 percent. ${ }^{1}$ As one might expect, there are variations by region and type of institution (the freshman decline is 6.6 percent for institutions in the Middle Atlantic states, for example), but the overall conclusion is clear. The 1980s have arrived largely in the form that was predicted.

But liberal arts colleges are a resilient form of human organization. While often small and generally quite specialized (a characteristic which makes them more vulnerable than diversified universities when their ecological niche is threatened), liberal arts colleges are also easier to manage, and they command much more loyalty and commitment from all of their employees, not just faculty. The people in these institutions are generally more willing to make personal sacrifices on behalf of the college. If a new direction is proposed in any organization, those involved must agree to pursue it vigorously or it will fail.

This intangible feature of small colleges is, I believe, a great asset as the 1980s unfold, but we are witnessing an attack on the financial base of private higher education without regard for institutional quality, prestige, or mission. The attack is such that all liberal arts colleges will have to change in important ways even if their goal is to remain largely the same. If demography were the only problem and the economy were strong and vital, the challenge would not be so severe. The resources necessary to finance useful adaptation would be much more available and, with good leadership, change might be accomplished efficiently and effectively.

However, student fee income, income from endowments, and income from new charitable gifts - the three major sources of income for private institutions - are all unfavorably affected by the combination of external factors currently operating.

Even for wealthy colleges student fee income is by far the largest single income source. Student fee income is, of course, threatened by the demographic decline: fewer students means less fee income for the private sector as a whole. But even colleges that manage to retain their enrollments and continue to have excess applicants can come to have a student fee income problem if they find that they are unable to pass the fees they need through the market without hurting their market share. Research at Carleton College $^{2}$ and the research of others ${ }^{3}$ indicates that students and their parents are extremely price-sensitive these days. To sustain its market share a college may well have to charge less than it needs to maintain its current level of quality. If price restraint is closely correlated with quality declines, and is not the result of real increases in efficiency (something that is very hard to accomplish in a labor-intensive organization), market-share declines may eventually produce enrollment declines, and a positive feedback loop of serious consequence will be the result.

Endowment income is also constrained in today's economy. For endowment income actually available to the operating budget not to decline in real terms, total return must consistently exceed the rate of inflation plus whatever percentage of current market value an institution chooses to spend. It is well to 
remember that endowments have generally not kept up with inflation in the last ten years even after one adds in the new gifts received. It is my understanding that only two private institutions-Swarthmore and Princetonhave earned so much and spent so little over the years that the value of each endowment unit has kept up with inflation (i.e., gifts made years ago have a market value today equal in real terms to what they were at the time of donation). At those institutions new endowment gifts have resulted in real additions to the budget and real increases in endowment market value.

A few other institutions have come close to holding their endowments constant in real terms over the last decade (that is, after the effects of inflation are taken out), but only by successful capital fund raising. Now, as all of you know, changes in the tax laws have decreased the incentive to give, and especially so for the very wealthy, those whose gifts make the biggest difference.

Finally, government gifts and grants in support of higher education have been drastically curtailed, and the prospect is for further cuts. Current gift income, which directly supports the operating budget, has therefore also been reduced just when the tax incentives for individuals to give have been cut.

Institutions that do nothing to become more attractive to students and capital, and which manage their endowments in the same old way, will find the going very tough. The severity of this financial crisis is such that even the best institutions will have to change. Because of declining demand (due to the demographic situation and high prices), because of the state of the American economy and its impact on endowments, and because of decreased incentives for donors to make charitable gifts, private institutions will have to restructure themselves. They must consider changes in the quantity, quality, and nature of their mission and programs.

\section{INSUFFICIENT}

\section{Capital Available}

If private institutions faced with the financial situation just described were to analyze their circumstances carefully and, if necessary, seek new ways to be of service, it would be a very good thing for the country. Apart from the pragmatics of it, boards of trustees and managements of private institutions have a fiduciary responsibility to adapt so as to continue to provide services that the public finds valuable. The assets of private colleges and universities exist largely as a result of gifts from individuals, corporations, and foundations for the purpose of helping to ensure in perpetuity that an important social need will be met: the education of the populace. Those of us who have some responsibility for the directions taken by our institutions have a legal and moral obligation to find valuable educational services to perform if demand for the services we now provide declines. We must change in response to the demographic and economic pressures of the 1980s in order to continue to be of service.

That said, we must acknowledge that the going will be very hard, because adaptive change requires capital to finance reallocation of resources and the launching of new ventures, and capital will be very difficult to obtain. Were interest rates not so high one might borrow the capital necessary for change, to be paid back from the income earned in new ventures. One could liquidate fixed assets, but many colleges are distant from urban areas where a variety of options might be pursued and, in any event, many college fixed assets were designed for specialized purposes, making them hard to convert to other uses. Another option is to spend endowments, and most colleges have done this at least to some extent, but if that is done one must find ways to compensate for the lost current income. Or, one might, as did late industrializing countries, extract capital from the peasants - in the case of colleges this would mean holding salaries and wages well below market in order to use the funds saved as capital. This kind of capital formation is most possible in denominational private colleges, where the commitment of employees to the institution is sometimes so strong that they may accept this kind of levy rather than see the institution fail. For most colleges, however, significant capital accumulation cannot be achieved in this way, and many would argue that it should not be so accumulated. Finally, as I have already indicated, gifts of capital will now be much harder to obtain.

I don't mean to suggest that capital will be completely unavailable; rather, I want to stress that the possibility of useful adaptation 
by private institutions to the demographic decline is significantly diminished because capital will be more scarce than it has been. Therefore, the demographic decline will have a quicker and more negative impact on private higher education than it otherwise might. American higher education will become more homogeneous in the next decade with the loss of strength in the private sector, and that is a loss for consumers in this country.

\section{LibraRies WILL BE \\ Especially Hard Hit}

Liberal arts college libraries will be especially hard hit by the circumstances just outlined. It is my understanding that, except at the best colleges and universities, libraries have already suffered greatly during the 1970s. Though there was no demographic decline to contend with, institutions faced high inflation and experienced extremely poor endowment investment results during the decade just ended. Because library materials expenditures are much easier to cut than people, and because materials budgets are large, many libraries have fallen way behind in collection development.

The 1980s, as I have argued, will be even more difficult financially than the 1970s, and it is likely that libraries will shoulder a disproportionate share of whatever further budget cuts colleges have to make. Some claim that there is a technological revolution just around the corner that will provide greater access to the kinds of information students and faculty need at much lower per-unit costs. Even if that optimistic result comes to pass, most institutions will not be able to adopt these laborsaving and material-saving library technologies, because large initial capital investments must be made while the savings come much later, and not enough capital will be available at prices institutions can afford.

All of this is occurring, ironically, precisely when libraries could finally hope to afford to collect scholarly materials at the same rate that they are produced. Derek Price, as you will certainly know, has long argued that the natural growth function, at least for scientific knowledge, is exponential. ${ }^{4}$ Some quibble about the fact that Price's indicator of the growth of knowledge is the growth of publi- cations, but that issue is quite secondary for librarians, whose real problem is coping with the growth of publications no matter what that says about the growth of knowledge.

Price has shown quite clearly that, over the entire history of Western science, publications, major discoveries, and other things about science one can count have grown exponentially. ${ }^{5}$ The same may very well have been true about other kinds of scholarly publications. Now, if there is something inexorable about this process, something intrinsic to the growth of knowledge, libraries have a serious problem. The doubling times for publications have been much shorter than those for acquisitions budgets, at least at the colleges with which I am familiar, and that has meant that each year a smaller proportion of the world's new knowledge was collected in the library. If one projects that situation into the future, one discovers that eventually, in the limit, a library like Carleton's would be collecting a proportion of the literature very close to zero. Even with the wonders of technology, which may significantly increase resource sharing, the prospect of collecting such a small proportion of the new knowledge produced is depressing.

But I want to argue, on the basis of my own research on publication patterns in physics, ${ }^{6}$ which I believe in this instance are generalizable, that we are about to experience not continued exponential growth but a leveling off and perhaps even a decline in the number of new scholarly publications produced annually. That is because the number of scholarly publications produced each year is closely related to the number of scholars working in research. ${ }^{7}$ Individual scholars tend to publish at a more or less constant rate over their professional lives and, in the aggregate, the number of papers per scholar is a constant. We have seen publication growing exponentially for a long time because the population of scholars publishing was growing exponentially. This is no longer true, at least in America, and the publications of American scholars make up the largest fraction of new acquisitions in American libraries.

In a simulation of article production patterns in high-energy physics, presented by me and my collaborators at a UNESCO conference in Dubrovnik, Yugoslavia, we showed article production in that part of physics lev- 
eling off by the mid-1980s. ${ }^{8}$ What happens after that is dependent upon rates of Ph.D. production and rates of retention in research - we call them "survival rates" - for those physicists already publishing. We have seen nothing that suggests that either increases in Ph.D. production or increases in retention are in the cards.

I believe that the same fundamental relationship between population and scholarly publication exists in all fields, though rates of publication do differ by field due to differences in research technology. Very high technology fields, such as experimental highenergy physics, can actually have much lower per capita publication rates because large groups of scientists are required to perform experiments that can take three to five years to complete.

All of this suggests to me that a library like Carleton's, by collecting a constant number of books and periodicals each year, which we have been able to afford and should be able to continue, can in a few years find itself collecting a constant, or even increasing, share of the literature published in English. If the Carleton library collects just the best of what is produced, which of course librarians always do, then it will be apparent how much more hopeful we can be about the structure of liberal arts college libraries.

\section{CoNCLUSION}

Sadly, as I have said, this opportunity to keep up comes just when the resources necessary even to stand still are not likely to be available to most college libraries. We deserve better, and those in this society who need and desire higher education of the highest quality deserve better.

Nevertheless, realistic and possibly successful strategies leading to useful, as opposed to mere, survival do exist. To repeat my earlier remarks: institutions need to undertake honest analyses of their strengths and weaknesses relative to the competition; they need to analyze the availability of new markets; they need to examine new ways to be of service; and they need to pursue aggressively the capital necessary to finance change.

\section{REFERENCES}

1. J. Magarrell, "Slight Enrollment Decline Seen for Private Institutions This Fall," Chronicle of Higher Education 23:12 (Sept. 2, 1981).

2. D. Brodigan, D. Sullivan, and L. Litten, "The Effect of Concern about Price on Application Choice between Private and Public Higher Education Institutions" (Paper presented at the annual forum of the Association for Institutional Research, Minneapolis, Minnesota, May 1981); L. Litten, D. Sullivan, D. Brodigan, and D. Morris, "Twixt Cup and Lip: Some Evidence on the Effect of Financial Concerns on College Choice" (Paper presented at the Midwest Regional Assembly of the College Board, Chicago, Illinois, February 1980).

3. R. Chapman, "Pricing Policy and the College Choice Process," Research in Higher Education 10:37-57 (1979); M. McPherson, "The Demand for Higher Education," in D. Breneman and C. Finn, Jr., eds., Public Policy and Private Higher Education (Washington, D.C.: The Brookings Institution, 1978), p.143-96.

4. D. J. de Solla Price, Little Science Big Science (New York: Columbia Univ. Pr., 1963), p.4-5.

5. Ibid., passim.

6. D. Sullivan, D. Koester, and D. Hywel White, "Survival in Particle Physics: An Analysis of Experimentalists' Persistence in Research," Scientia Yugoslavica 6:191-201 (1980).

7. D. Sullivan, D. Hywel White, and E. J. Barboni, "The State of a Science: Indicators in the Specialty of Weak Interactions," Social Studies of Science 7:185 (1977).

8. Sullivan, Koester, and White, "Survival in Particle Physics,"p.199. 